Portland State University

PDXScholar

4-1-1985

\title{
The Effect of Glaciers on Streamflow Variations
}

Andrew G. Fountain

Portland State University, andrew@pdx.edu

Wendell V. Tangborn

Follow this and additional works at: https://pdxscholar.library.pdx.edu/geology_fac

Part of the Geology Commons, and the Glaciology Commons

Let us know how access to this document benefits you.

\section{Citation Details}

Fountain, A. G., and W. V. Tangborn (1985), The Effect of Glaciers on Streamflow Variations, Water Resour. Res., 21(4), 579-586, doi:10.1029/WR021i004p00579

This Article is brought to you for free and open access. It has been accepted for inclusion in Geology Faculty Publications and Presentations by an authorized administrator of PDXScholar. Please contact us if we can make this document more accessible: pdxscholar@pdx.edu. 


\title{
The Effect of Glaciers on Streamflow Variations
}

\author{
ANDREW G. FOUNTAIN \\ Project Office-Glaciology, U. S. Geological Survey, Tacoma, Washington \\ WENDELL V. TANGBORN \\ Hymet Company, Seattle, Washington
}

\begin{abstract}
The effect of temperate glaciers on runof variations is examined for the North Cascade Mountains of Washington State. The principal influences of glaciers on streamflow are often unexpected contributions to streamflow volume, a delay of the maximum seasonal flow, and a decrease in annual and monthly variation of runoff. The delay of maximum flow is caused by temporary englacial storage of spring meltwater and by peak meltwater production occurring in midsummer. The englacial storage, for one case, is $54 \%$ of the potential May runoff. An algorithm is presented that calculates the coefficient of variation of runoff for any arbitrary glacier cover. The results suggest that a minimum in year-to-year variation occurs for basins about $36 \%$ glacierized. On a month-to-month basis, maximum variation occurs in July and August for basins with less than $10 \%$ glacier cover but is a minimum for basins with glacier covers greater than $30 \%$.
\end{abstract}

\section{INTRODUCTION}

Glaciers are frozen reservoirs of water. The residence time of potential runoff ranges from a few hours to thousands of years, depending on the size and type of glacier, the season of precipitation occurrence, and location on the glacier of initial precipitation deposition. The release of water from storage greatly affects the local hydrologic cycle by contributing to streamflow in otherwise low flow periods. Understanding these effects on basin runoff is of both theoretical and practical importance. For example, hydroelectric power generation hinges on the quantity and timing of the water supply, and the eflicient operation of the facility depends on the prediction of these factors. The prediction of runoff is not easy in simple basins, and the presence of glaciers greatly complicates the situation. The study of glacier runoff also concerns water flow through glaciers, which influences glacier movement [Paterson, 1981].

In the state of Washington there are more than $1,000 \mathrm{gla}-$ ciers [Post et al., 1971], and as the hydroelectric potential and other water uses in the state become fully realized, the importance of glacier runoff will increase. One of the first to deal with the influence of glaciers on runoff in the Pacific Northwest was Henshaw [1933] who found a lower annual (year-toyear) variation of runoff from glacierized basins. Meier and Tangborn [1961] demonstrated a longer delay in the summer runoff maximum from increasingly glacierized basins. They also elucidated the effect of glaciers in compensating for the year-to-year variation in precipitation, whereby a glacier will produce more meltwater in a warm and dry year than in a cool and wet one, thus reducing the annual fluctuations of runoff. The occurrence, in July and August, of peak runoff from a Pacific Northwest glacier was shown by Meier [1969] to coincide with a seasonal minimum in cloud cover during a period of high insolation and low snow/ice albedo. The summer-to-summer (May-Sept) variation of runoff was compared with the basin fraction of glacier cover by Krimmel and Tangborn [1974]; they showed that the mininum variation in

Copyright 1985 by the American Geophysical Union.

Paper number 4W1531.

0043-1397/85/004W-1531\$05.00 runoff occurs at about $30 \%$ glacier cover. Meier and Tangborn [1961], Meier [1969], and Krimmel and Tangborn [1974] all discussed the independence of annual runoff variation, in partially glacierized basins, from annual precipitation variation.

Although these studies have examined the influence of glaciers on runoff in the Pacific Northwest, it is the purpose of this paper to examine more fully the delay of runoff caused by glaciers and their effect on monthly and annual streamflow variation.

\section{APPROACH}

The salient features of glacial influence on basin runoff can be revealed by comparing runoff data from glacierized and nonglacierized basins [Meier and Tangborn, 1961]. The critical assumption in this comparison is that the precipitation characteristics of the glacierized and nonglacierized basins are similar. For this reason, the study is limited to a relatively small, well-defined region in the Pacific Northwest. Most of the glacierized basins in the state of Washington were identified by using two reports: Post et al. [1971] and Rasmussen and Tangborn [1976]. Several additional basins were identified from topographic maps. The nonglacierized basins were chosen in the same mountainous region as the glacierized ones and were selected on the basis of their area, altitude, and location. The most desirable unglacierized basins were those that had area and altitudes similar to the glacierized ones. The source of runoff data was the National Water Data Storage and Retrieval System, WATSTORE [U.S. Geological Survey, 1975]. All records were examined to eliminate those influenced by water diversion and regulation. Data from the compiled stations are presented in Table 1 . To supplement this data set and to serve as an independent check, data were used from climatically similar Southeast Alaska (Table 2).

\section{REgION DESCRIPTION}

The study centered on the North Cascades region in the state of Washington, which for the purpose of this report is bounded on the northern edge by the Canadian border, by Mount Rainier on the southern edge, and extends from the eastern face of the North Cascade Range to the lowlands along Puget Sound (Figure 1). Washington is the most gla- 
TABLE 1. Drainage Basins in Washington State and Pertinent Data

\begin{tabular}{|c|c|c|c|c|c|c|c|}
\hline & $\begin{array}{c}\text { Station } \\
\text { ID }\end{array}$ & $\begin{array}{l}\text { Period } \\
\text { of Record }\end{array}$ & $\begin{array}{c}\text { Mean Basin } \\
\text { Elevation, } \\
\mathbf{m}\end{array}$ & $\begin{array}{l}\text { Area, } \\
\mathrm{km}^{2}\end{array}$ & $\begin{array}{c}\text { Percent } \\
\text { Glacier } \\
\text { Cover }\end{array}$ & $\begin{array}{c}\text { Mean } \\
\text { Annual } \\
\text { Runoff, } \\
\text { m }\end{array}$ & $\begin{array}{c}\text { Annual } \\
\text { Coefficient } \\
\text { of Variation }\end{array}$ \\
\hline Nisqually River & 825 & $1942-1982$ & 1225 & 344.5 & 5.00 & 2.02 & 0.164 \\
\hline Puyallup River & 920 & 1909-1982 & 1250 & 240.4 & 8.70 & 1.97 & 0.135 \\
\hline Carbon River & 939 & $1966-1978$ & 1220 & 197.4 & 5.70 & 1.96 & 0.173 \\
\hline South Fork Cedar River & 1140 & $1945-1982$ & 1067 & 15.5 & 0 & 2.20 & 0.197 \\
\hline Cedar River & 1150 & $1946-1982$ & 985 & 105.4 & 0 & 2.29 & 0.195 \\
\hline Rex River & 1155 & $1946-1982$ & 1024 & 34.7 & 0 & 2.71 & 0.193 \\
\hline South Fork Skykomish River & 1330 & $1903-1982$ & 1158 & 919.4 & 0.43 & 2.37 & 0.214 \\
\hline North Fork Skykomish River & 1345 & 1929-1982 & 1127 & 1385.6 & 0.40 & 2.55 & 0.223 \\
\hline Wallace River & 1350 & $1929-1982$ & 811 & 49.2 & 0 & 3.04 & 0.189 \\
\hline Sultan River & 1375 & 1934-1971 & 951 & 193.0 & 0.10 & 3.68 & 0.171 \\
\hline Woods Creek & 1410 & $1946-1972$ & 191 & 146.1 & $\mathbf{0}$ & 0.95 & 0.185 \\
\hline Middle Fork Snoqualmic River & 1413 & $1961-1982$ & 1131 & 398.9 & 0.25 & 2.87 & 0.216 \\
\hline North Fork Snoqualmie River & 1420 & $1930-1982$ & 975 & 165.8 & 0 & 2.70 & 0.196 \\
\hline South Fork Snoqualmie River & 1434 & $1961-1982$ & 1033 & 107.7 & 0 & 2.52 & 0.221 \\
\hline South Fork Stillaguamish River & 1610 & $1928-1981$ & 793 & 308.2 & 0 & 3.11 & 0.204 \\
\hline Squire Creek & 1650 & $1950-1969$ & 771 & 51.8 & 0.76 & 3.20 & 0.167 \\
\hline Pilchuck Creek & 1685 & 1929-1982 & 393 & 134.7 & 0 & 1.86 & 0.196 \\
\hline Big Beaver Creek & 1720 & $1940-1969$ & 1341 & 163.7 & 0.39 & 1.56 & 0.183 \\
\hline Ruby Creek & 1735 & $1949-1969$ & 1737 & 533.5 & 1.00 & 1.19 & 0.177 \\
\hline Thunder Creek & 1755 & $1931-1982$ & 1768 & 271.9 & 14.20 & 2.02 & 0.138 \\
\hline Stetattle Creek & 1775 & 1914-1982 & 1524 & 57.0 & 2.30 & 2.88 & 0.187 \\
\hline Newhalem Creek & 1781 & $1961-1982$ & 1262 & 72.3 & 0.41 & 2.14 & 0.212 \\
\hline South Fork Cascade River & 1811 & $1957-1982$ & 1902 & 6.1 & 53.30 & 3.83 & 0.092 \\
\hline Salix Creek & 1812 & $1961-1981$ & 1643 & 0.2 & 0 & 3.15 & 0.200 \\
\hline Cascade River & 1825 & $1929-1980$ & 1341 & 445.5 & 4.2 & 2.06 & 0.180 \\
\hline Sauk River & 1860 & $1918-1982$ & 1127 & 393.7 & 1.00 & 2.58 & 0.202 \\
\hline Alder River & 1960 & $1943-1971$ & 390 & 27.7 & $\mathbf{0}$ & 1.14 & 0.218 \\
\hline North Fork Nooksack River & 2050 & $1938-1982$ & 1311 & 271.9 & 6.10 & 2.54 & 0.151 \\
\hline South Fork Nooksack River & 2090 & $1934-1982$ & 914 & 266.8 & 0 & 2.47 & 0.176 \\
\hline Steheken River & 4510 & $1911-1982$ & 1564 & 831.4 & 3.40 & 1.52 & 0.216 \\
\hline Kachess River & 4760 & $1904-1978$ & 1106 & 164.7 & 0 & 1.58 & 0.255 \\
\hline Cle Elum River & 4790 & $1904-1978$ & 1323 & 525.8 & 0.30 & 1.58 & 0.205 \\
\hline
\end{tabular}

Standard U.S. Geological Survey station ID's can be reconstructed by multiplying the given ID by 100 and adding $12,000,000$.

cierized state of the contiguous United States, and the North Cascades contain more than $90 \%$ of the state's glaciers. The topography varies from broad, flat, lowlands to deep, narrow valleys in the alpine region.
The climate of the western slope of the Cascades is maritime with typically mild winters of high precipitation and cool, drier summers. Snow accumulation of $8-10 \mathrm{~m}$ near an altitude of $2,000 \mathrm{~m}$ is common. On the eastern side the climate is more

TABLE 2. Drainage Basins in Southeast Alaska and Pertinent Data

\begin{tabular}{lcccrrrr}
\hline & Station & $\begin{array}{c}\text { Period } \\
\text { of Record }\end{array}$ & $\begin{array}{c}\text { Mean Basin } \\
\text { Elevation, } \\
\mathrm{m}\end{array}$ & $\begin{array}{c}\text { Area, } \\
\mathbf{k m}^{2}\end{array}$ & $\begin{array}{c}\text { Percent } \\
\text { Glacier } \\
\text { Cover }\end{array}$ & $\begin{array}{c}\text { Mean } \\
\text { Rnnual } \\
\text { Runoff, } \\
\mathrm{m}\end{array}$ & $\begin{array}{c}\text { Annual } \\
\text { Coefficient } \\
\text { of Variation }\end{array}$ \\
\hline Harding River & 220 & $1952-1981$ & 732 & 174.6 & 9 & 3.71 & 0.100 \\
Cascade River & 260 & $1918-1973$ & 964 & 59.6 & 13 & 3.73 & 0.112 \\
Long River & 340 & $1917-1973$ & 732 & 84.2 & 22 & 4.81 & 0.159 \\
Dorothy Creek & 400 & $1930-1968$ & 946 & 39.4 & 16 & 3.20 & 0.128 \\
Carlson Creek & 440 & $1952-1961$ & 671 & 62.9 & 10 & 4.77 & 0.156 \\
Sheep Creek & 480 & $1919-1973$ & 580 & 11.8 & 2 & 3.64 & 0.167 \\
Gold Creek & 500 & $1918-1981$ & 732 & 25.3 & 8 & 3.77 & 0.161 \\
Lemon Creek & 520 & $1952-1973$ & 1046 & 31.3 & 67 & 4.32 & 0.124 \\
Mendenhall River & 525 & $1966-1981$ & 994 & 220.4 & 66 & 4.56 & 0.136 \\
Montana Creek & 528 & $1966-1976$ & 458 & 40.1 & 3 & 2.31 & 0.150 \\
Lake Creek & 538 & $1964-1973$ & 357 & 6.5 & 0 & 1.75 & 0.170 \\
West Creek & 562 & $1963-1977$ & 1037 & 111.9 & 26 & 2.64 & 0.136 \\
Perseverance Creek & 600 & $1932-1969$ & 409 & 7.3 & 0 & 4.49 & 0.131 \\
Sawmill Creek & 880 & $1921-1957$ & 732 & 101.0 & 3 & 4.24 & 0.170 \\
Baranof River & 980 & $1916-1974$ & 610 & 82.9 & 12 & 4.44 & 0.123 \\
Takatz Creek & 1000 & $1952-1969$ & 702 & 45.3 & 19 & 5.03 & 0.095 \\
Hasselborg Creek & 1020 & $1952-1968$ & 366 & 145.6 & 1 & 1.95 & 0.116 \\
\hline
\end{tabular}

Standard U.S. Geological Survey station ID's can be reconstructed by multiplying the given ID by 100 and adding $15,000,000$. 


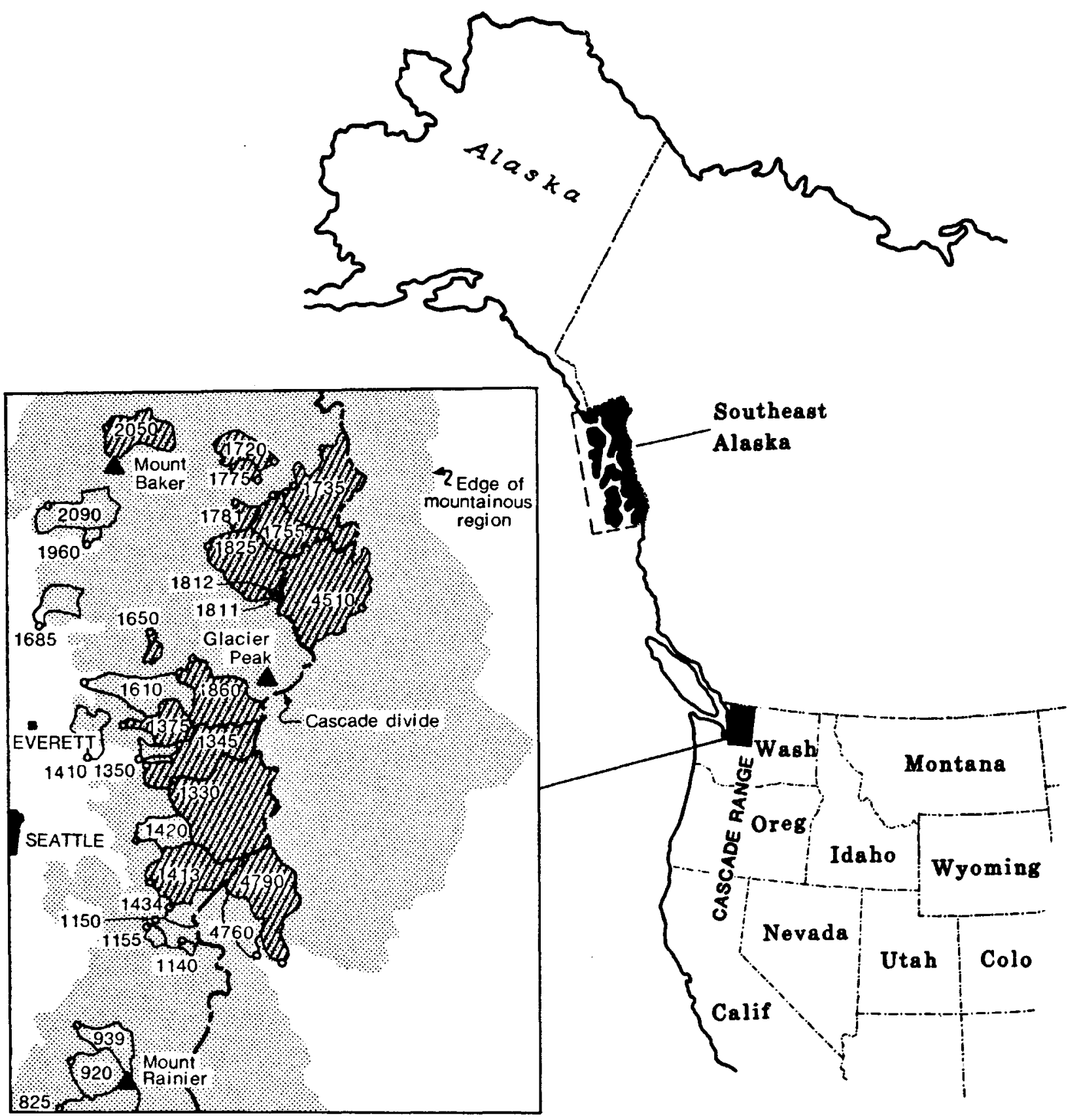

\section{STUDY AREA}

Fig. 1. Study region in the North Cascade Mountains of the State of Washington and position of Southeast Alaska where supplemental basins are located. Each basin used in this paper is outlined in the study area and includes the station number which refers to Table 1 ; hatching indicates a basin includes glaciers.

continental with colder winters, hotter summers, and much less precipitation. Maximum precipitation in both regions occurs during the winter, and the minimum occurs in midsummer. Because most of the winter precipitation at higher altitudes occurs as snow, the maximum runoff from glacierized basins is delayed until spring.

\section{Glacier Contribution to RunofF}

The significance of glacial runoff to the volume of runoff from a basin is dependent on the "health" and size of the glaciers. A glacier in equilibrium neither grows nor shrinks and thus has little effect on the annual volume of streamflow.
If the glacier experiences a positive net mass change, however, some potential runoff is stored as ice, which diminishes the streamflow. This effect normally has little noticeable impact because a positive glacier balance usually occurs during a year of high precipitation, which produces a generous water supply. Runoff resulting from a glacier's net mass loss augments local streamflow, which can be especially important during periods of drought.

The relative effect of a glacier's mass loss on basin runoff can be calculated by multiplying the glacier mass balance (averaged over the glacier area) by the fraction of the basin glacierized and dividing by the mean specific runoff (volume divided by basin area) from an unglacierized basin of similar 


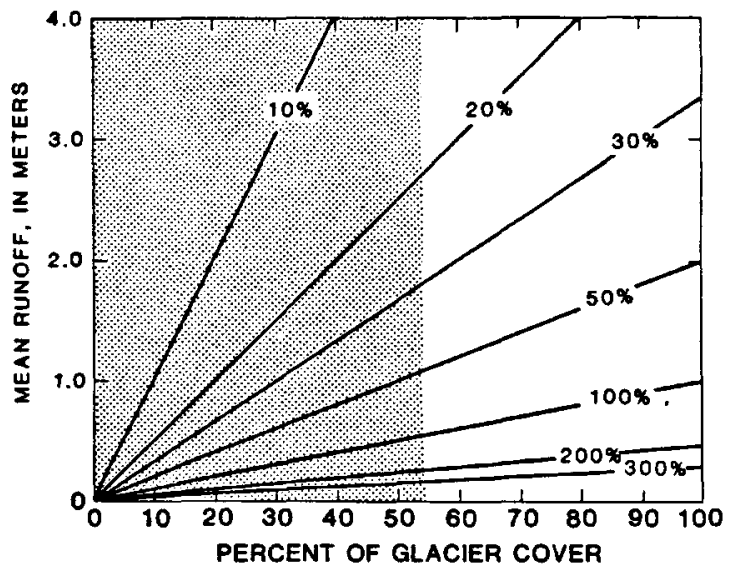

Fig. 2. The percent increase in specific runoff from a glacierized basin over a nonglacierized basin of similar precipitation characteristics as a function of mean specific runoff and percentage of basin glacierized, assuming an annual net glacier mass balance of $-1.0 \mathrm{~m}$ water equivalent; shaded region indicates the extent of glacierized basins which are gauged in the North Cascades.

precipitation characteristics. The unglacierized basin's runoff is used as an approximation of what the subject basin would yield in runoff were it not for the presence of the glacier. The results of this calculation, percent increased runoff, are shown in Figure 2 as a function of percent glacier cover and mean runoff from an unglacierized basin, given a glacier annual mass balance value of negative $1 \mathrm{~m}$ water equivalent (WEQ). The shaded region concerns the North Cascades where no currently gauged basin exceeds $53 \%$ glacier cover. If a basin has a $20 \%$ glacier cover and the unglacierized basins nearby have a mean annual runoff of $2 \mathrm{~m}$, then the annual runoff from the glacierized basin would be increased by about $10 \%$ for a 1-m WEQ glacier mass loss. Most of this meltwater occurs during July and August when the skies are less cloudy and precipitation is low [Meier, 1969]. The unglacierized runoff, however, is low during these months and constitutes often less than $15 \%$ of the annual runoff. If glaciers are present and cover $20 \%$ of the basin area, then the increase in runoff for the summer period will be as much as $50 \%$.

\section{Peak Runoff Delay}

The delay of the peak summer flow is shown by plotting the monthly fraction of mean annual runoff for basins of different glacier cover (Figure 3). A monthly runoff record for a hypothetical basin of $100 \%$ glacier cover was generated by subtracting an adjusted value of the monthly discharge from a basin of $0 \%$ glacier cover, Salix (station 1812), from the discharge from a basin of $53 \%$ glacier cover, South Cascade (1811), and dividing by the area of the glacier. The adjusted value is the ratio between the ice free area of South Cascade and the area of Salix. Salix basin is located adjacent to South Cascade basin and both are similar in altitude and precipitation accumulation. The unglacierized basin (station 1140) shows a bimodal annual distribution of runoff caused by a winter maximum in precipitation that occurs as rain at the lower altitudes of the basin and a spring maximum from melting of the snowpack at higher altitudes. For unglacierized basins the maximum runoff occurs in May. For glacierized basins, however, maximum runoff occurs later and later as the percentage of glacier cover increases. The delay is caused, in part, by later snow melting with increasing altitude. A plot (not shown) of the time of peak seasonal flow occurrence from an unglacierized basin as a function of basin mean altitude shows this relationship to be linear and of small influence in comparison with the parabolic relationship between time of maximum seasonal runoff and percent glacier cover (Figure 4). The reasons for a glacier-caused delay in runoff can be found by examining the elements of runoff.

In the North Cascades, the components of summer runoff are snowmelt and precipitation; if glaciers are present, icemelt and water released from internal glacier storage [Stenborg, 1970; Tangborn et al., 1975; Larson, 1978] also contribute. The principal components of runoff from glacierized basins are snowmelt [Rasmussen and Tangborn, 1976] and icemelt, whereas precipitation and the release of water from internal storage are relatively small contributions to summer streamflow. The quantity of meltwater from an unglacierized basin is limited by the snowpack volume. In contrast, a glacierized basin has a relatively unlimited meltwater source, and the quantity of melt produced is only limited by the available energy. The variation in meltwater production is controlled by solar radiation, cloud cover, and snow-ice albedo, and the combined effectiveness of these factors for meltwater production reaches a maximum in the North Cascades in late July and early August [Meier, 1969]. The snowpack generally disappears in much of the North Cascades by late June, already having made its significant contribution to runoff. A glacier, however, continues to melt at an increasing rate until midsummer. This peak melt rate in midsummer is one cause for the late appearance of maximum runoff from glacierized basins.

Another delay mechanism is the temporary internal liquid storage of meltwater in the glacier. Tangborn et al. [1975] calculated that in May of $1970,0.20 \mathrm{~m}$ of potential specific runoff was stored in South Cascade Glacier. The specific
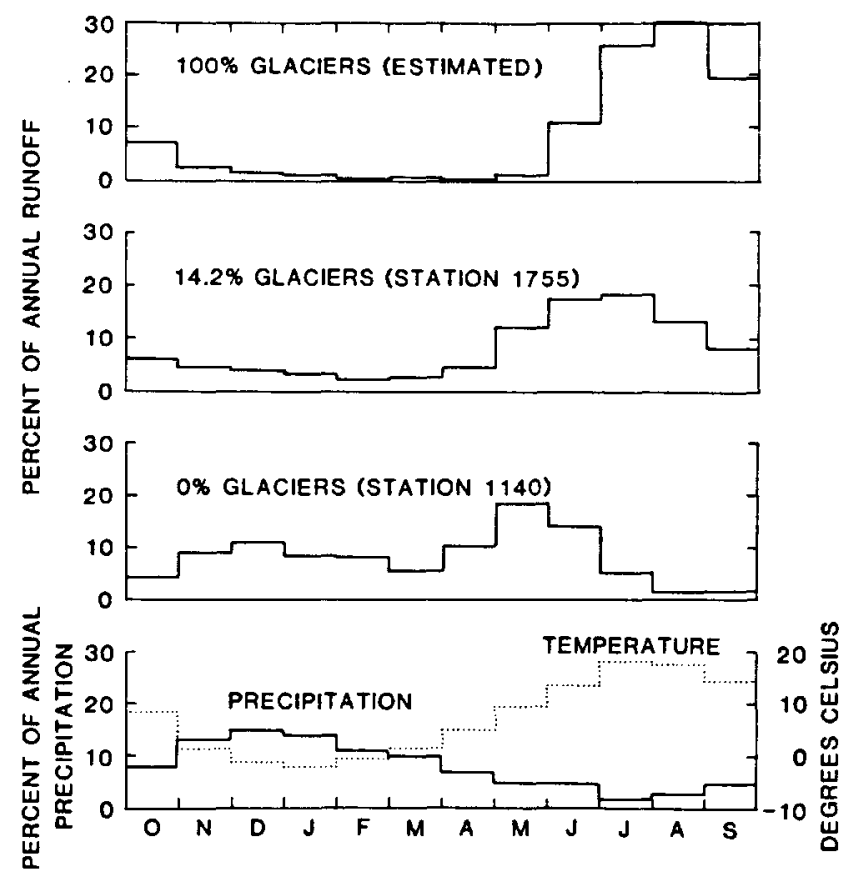

Fig. 3. Monthly fraction of the annual specific runoff for basins of various glacier covers. The monthly fraction of precipitation and mean monthly temperature (Snoqualmine Pass, Washington) are included for comparison. 


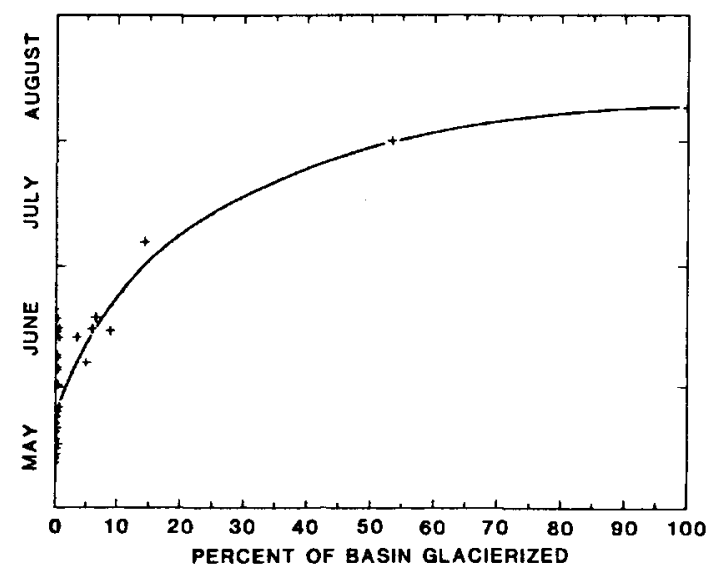

Fig. 4. Timing of peak specific runoff as a function of glacier cover for basins in the North Cascades, Washington.

runoff from the adjacent unglacierized basin (Salix) for the same period was $0.37 \mathrm{~m}$. Thus $54 \%$ of the total possible May runoff was temporarily stored in the glacier before being released during the following months.

One noteworthy observation of Figure 4 is that the maximum flow may be delayed as much as a month if the basin glacier cover changes from 5 to $15 \%$, whereas it is delayed only about 2 more weeks as the glacier cover increases from 50 to $100 \%$. This has important implications for hydroelectric site selection and for the effects of climate change on streamflow. If the climate changes, the glaciers will respond by changing size, which will result in a change in the time of appearance of the maximum streamflow, especially for basins with small glacier covers.

The scatter of points in Figure 4, particularly below $1 \%$ glacierization, has two possible explanations. The aspect (direction which the basin faces) of the basin exerts an influence on the rate of meltwater production from a snowpack and may be important for nonglacierized basins. Glacierized basins in the North Cascades tend to be north-facing drainages, thus naturally eliminating the influence of aspect. The effect of basin altitude, while not as important an influence on peak flow delay as the effect of glacier cover, is a significant factor in nonglacierized basins. The combined influence of aspect and altitude may cause the large degree of scatter observed in the nonglacierized basins, and those with only minor glacier cover.

\section{VARIATION}

The variations in runoff from basins of different discharges were compared by a dimensionless parameter, the coefficient of variation $(C)$. It is calculated by dividing the standard deviation of the runoff by the mean:

$$
C=\frac{\sigma}{\bar{R}}
$$

The annual coefficient of variation, calculated from annual specific runoff values, was plotted for each station (Tables 1 and 2) versus the percent glacier cover of the basin (Figure 5). The variation seems to decrease with increasing basin glacierization, but unfortunately not enough data are available to define the relationship over the entire range of possible glacier coverages, despite the addition of data from the climatically similar southeast Alaska.

A scheme was developed to create runoff records for hypothetical basins of any glacier cover by combining the specific runoff records of two basins having known but different glacier cover. The resulting glacier cover of the hypothetical basin depends on the fractional combination of the two original records. This procedure is analogous to having a number of gauging sites on the same river, successively downriver from its source at the glacier. The mathematical technique is a linear combination of variables whose result has statistical properties that depend on the statistics of the original variables and allows extrapolation to any fraction of glacierization. To determine this curve, define the linear combination

$$
X=f G+(1-f) U
$$

where $G$ and $U$ are specific runoff values of a completely glacierized basin and glacier-free basin, respectively. $X$ is the estimated runoff from a basin with a fraction, $f$, of the total area covered by glaciers. The mean and variance of $X$ are

$$
\begin{gathered}
\bar{X}=f \bar{G}+(1-f) \bar{U} \\
\mathrm{~V}_{x}=f^{2} V_{G}+(1-f)^{2} V_{U}+2 f(1-f) r_{G U} \sqrt{V_{G}} \sqrt{V_{U}}
\end{gathered}
$$

[Ostle and Mensing, 1975]. The bar indicates a mean value, $V$ is the variance, and $r_{G U}$ is the correlation between $G$ and $U$.

These equations can not be implemented because of the lack of runoff records from completely glacier covered basins. However, a slightly different approach can be used to reach the same results. Define a different linear combination with weights $a_{1}$ and $a_{2}$ :

$$
R=a_{1} R_{1}+a_{2} R_{2}
$$

where $R_{1}$ and $R_{2}$ are specific runoff values of two basins of different glacier cover. Because the weights are constrained by $a_{1}+a_{2}=1$, the value for the weight $a_{1}$ may be calculated from

$$
f=a_{1} f_{1}+\left(1-a_{1}\right) f_{2}
$$

where $f_{1}$ and $f_{2}$ are the fractions of glacier cover in basins with runoff $R_{1}$ and $R_{2}$ to give $f$ as the glacier cover of the combined basin. Equation (3) yields

$$
a_{1}=\frac{f-f_{2}}{f_{1}-f_{2}}
$$

The mean and variance of $R$ are

$$
\begin{gathered}
\bar{R}=a_{1} \bar{R}_{1}+a_{2} \bar{R}_{2} \\
V_{R}=a_{1}{ }^{2} V_{1}+a_{2}{ }^{2} V_{2}+2 a_{1} a_{2} r_{12} \sqrt{V_{1}} \sqrt{V_{2}}
\end{gathered}
$$

[Ostle and Mensing, 1975]. The bar indicates a mean value, $V$ is the variance, and $r_{12}$ is the correlation between $R_{1}$ and $R_{2}$.

It is readily apparent that (5) and (6), which use runoff records from two basins of any glacier cover, are a generalization of the former equations using runoff records from two basins, one of which is completely glacier covered and the other is glacier-free. 


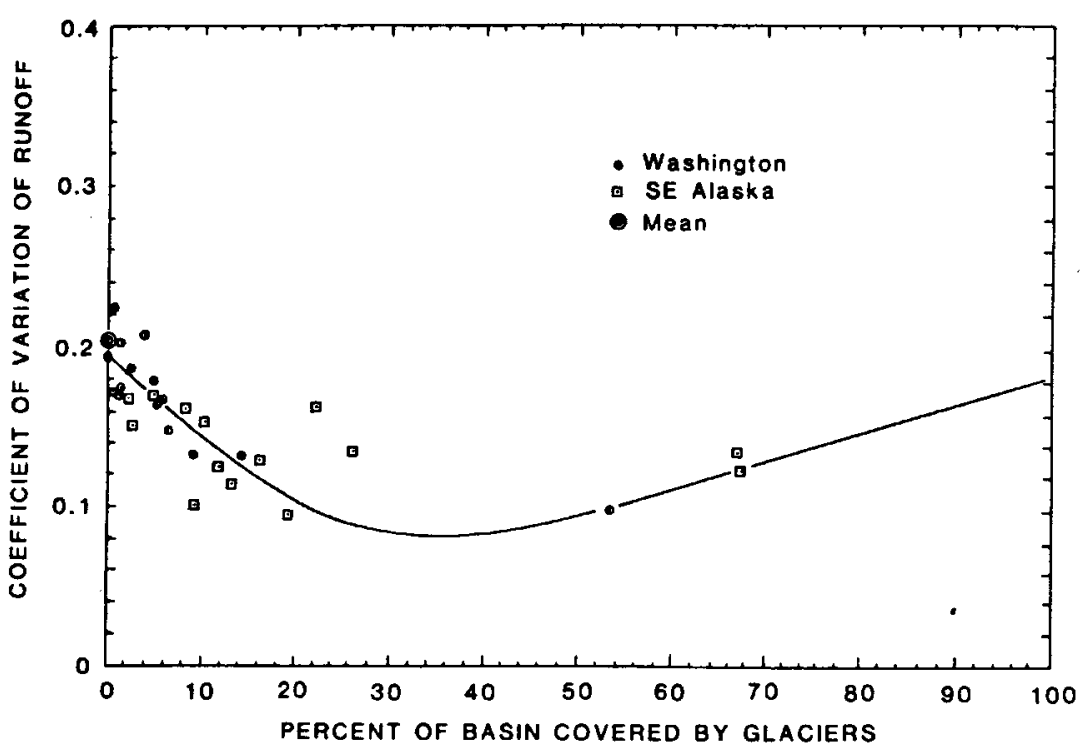

Fig. 5. Coefficient of variation of annual specific runoft values versus the fraction of the drainage basin glacierized. Circles are Washington stations; squares are Alaska sites. The mean value for unglacierized basins is indicated by the double circle. The solid line is based on (7), in which the two basins are Salix (1812) and South Cascade (1811).

It can be shown that the relationship between the two approaches is

$$
\begin{aligned}
& {\left[\begin{array}{r}
V_{1} \\
V_{2} \\
r_{12} \sqrt{V_{1}} \sqrt{V_{2}}
\end{array}\right] } \\
&= \\
& \qquad\left[\begin{array}{ccc}
f_{1}{ }^{2} & \left(1-f_{1}\right)^{2} & 2 f_{1}\left(1-f_{1}\right) \\
f_{2}{ }^{2} & \left(1-f_{2}\right)^{2} & 2 f_{2}\left(1-f_{2}\right) \\
f_{1} f_{2} & \left(1-f_{1}\right)\left(1-f_{2}\right) & f_{1}+f_{2}-2 f_{1} f_{2}
\end{array}\right] \\
& \cdot\left[\begin{array}{cc} 
& \\
V_{G} & V_{U} \\
r_{G V} \sqrt{V_{G}} \sqrt{V_{v}}
\end{array}\right]
\end{aligned}
$$

Theoretically, $V_{G}, V_{U}$, and $\left(r_{G U} \sqrt{V_{G}} \sqrt{V_{U}}\right)$ are constant for different values of $V_{1}, V_{2}$, and $\left.r_{12} \sqrt{V_{1}} \sqrt{V_{2}}\right)$ within any region of similar hydrological characteristics. However, because apparent values of $V_{G}, V_{v}$, and $\left(r_{G} \sqrt{V_{G}} \sqrt{V_{v}}\right)$ will probably differ for different initial basins, expectation values can be calculated for the geographic region under study. Solving for $V_{G}, V_{U}$, and $\left(r_{G U} \sqrt{V_{G}} \sqrt{V_{U}}\right)$ yields

$$
\begin{aligned}
& {\left[\begin{array}{c}
V_{G} \\
V_{U} \\
r_{G U} \sqrt{V_{G}} \sqrt{V_{v}}
\end{array}\right]} \\
& =\frac{1}{\left(f_{1}-f_{2}\right)^{2}}\left[\begin{array}{ccc}
\left(1-f_{2}\right)^{2} & \left(1-f_{1}\right)^{2} & -2\left(1-f_{1}\right)\left(1-f_{2}\right) \\
f_{2}{ }^{2} & f_{1}{ }^{2} & -2 f_{1} f_{2} \\
-f_{2}\left(1-f_{2}\right) & -f_{1}\left(1-f_{1}\right) & f_{1}+f_{2}-2 f_{1} f_{2}
\end{array}\right]
\end{aligned}
$$$$
\cdot\left[\begin{array}{c}
V_{1} \\
V_{2} \\
r_{12} \sqrt{V_{1}} \sqrt{V_{2}}
\end{array}\right]
$$

Substituting (5) and (6) into 1 and expressing $C$ in terms of $a_{1}$ yields

$$
\begin{aligned}
& C= \\
& \frac{\left[\left(V_{1}+V_{2}-2 r_{12} \sqrt{V_{1}} \sqrt{V_{2}}\right) a_{1}^{2}+2\left(r_{12} \sqrt{V_{1}} \sqrt{V_{2}}-V_{2}\right) a_{1}+V_{2}\right]^{1 / 2}}{\left(\bar{R}_{1}-\bar{R}_{2}\right) a_{1}+\bar{R}_{2}}
\end{aligned}
$$

The records used in calculating $C$ as a function of glacier cover were Salix (1812) and South Cascade (1811), because they are neighboring basins having similar precipitation characteristics but large differences in glacier cover, 0 and $53 \%$, respectively. The calculated curve in Figure 5 exhibits a minimum of 0.08 at $36 \%$ glacier cover and at the extremes of glacier cover, 0 and $100 \%$, have similar maximum values of 0.20 and 0.18 . The 0.12 decrease in runoff variation between 0 and $36 \%$ glacier cover can be significant for hydroelectric facilities without a large reservoir.

The Pacific Northwest coast is blessed with plentiful and relatively dependable precipitation, so the variability of runoff from unglacierized basins is low, whereas in more arid regions the streamflow variations from unglacierized basins are much larger. Data from basins in Northwest China [Zuming, 1982] show that unglacierized basins have annual specific runoff variations of about 0.40 , but some of the partially glacierized basins have variations of about 0.10 . The 0.30 decrease in variation of annual streamflow from glacierized basins in this region strongly suggests locations for facilities that depend on a reliable source of water such as for hydroelectric development and intensive farming. The coefficient of variation data, derived from the work by Zuming [1982], when plotted as a function of percent basin covered by glaciers, is similar to the results shown in Figure 5, which suggests the general applicability of the technique in spite of climatic differences.

The estimation of the coefficient of variation versus glacier cover gave similar results for different pairs of basins as long as they were both mountainous basins of more than about $10 \%$ difference in glacier cover. Estimation values for $V_{G}$ and $r_{G U}$ can not be calculated for the North Cascades because a data set consisting of many pairs of basins with a wide range of glacierizations does not exist. However, several basins of 
different glacier cover were used with South Cascade to approximate these values and the error associated with them: $V_{G}$ is approximately $0.79 \pm 0.05, r_{G U}$ is $-0.60 \pm 0.02$, and $C$ at $f=1$ is $0.17 \pm 0.02$.

The sensitivity of this technique of estimating the statistics $\bar{G}, V_{G}$, and $C$ of a completely glacier covered basin is fairly small. A $5 \%$ error in the estimate of glacier cover for South Cascade results in a 3\% error in both the mean, $G$, and $C$, and a $14 \%$ error in $V_{G}$. A $5 \%$ error in the area of South Cascade basin, which affects the conversion from volume to specific runoff, results in an $8 \%$ error in $G$, a $7 \%$ error in $V_{G}$, and a $6 \%$ error in the coefficient of variation, $C$.

To examine the seasonal difference in the effect of glaciers on runoff, the coefficient of variation was calculated for each month. Figure 6 shows the monthly coefficient of variation for three basins of different glacier cover. The monthly coefficient of variation for the unglacierized basin (station 1610) is typical of those in the North Cascades. The minimum in April and May is caused by variations in the spring snowmelt compensating for the deviations in precipitation. The snowmelt rate is greater during drier, warmer periods than during wetter, cooler ones, thus reducing the streamflow variation. During July, August, and September the monthly runof is most variable because of the irregular nature of the convective storms, which bring much of the rainfall during this season, and because of the lack of the moderating influence of a melting snow cover.

The monthly streamflow variation for a basin (station 1755) $14.2 \%$ glacierized is much different from that of a nonglacierized basin. The variation in the monthly flow is fairly small during the summer, reflecting the compensating effects of melting glacier ice.

The runoff of a hypothetical, completely glacierized basin
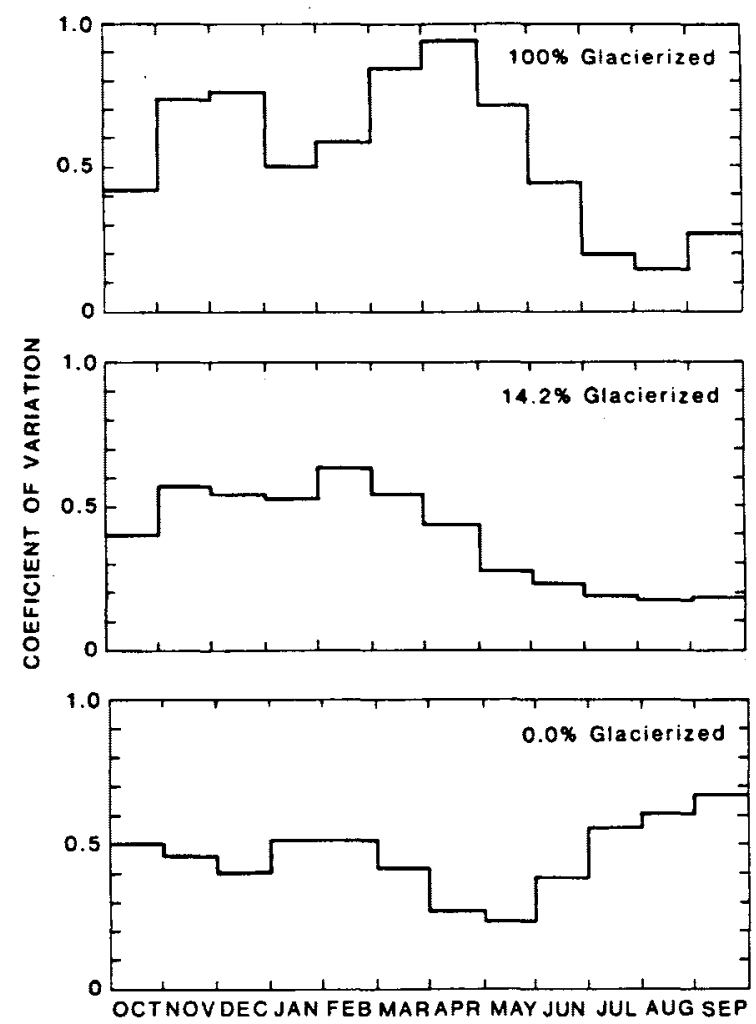

Fig. 6. Monthly coefficient of variation for basins of different glacier cover. was estimated, from Salix and South Cascade, as before, for peak runoff delay. The graph shows a spring maximum and summer minimum in runoff variation.

The $C$ values for April and May are somewhat speculative because of assumptions made about the relationship of the unglacierized runoff to the glacierized runoff during these months. The glacial storage of water during the spring disrupts the melt-runoff relationships that hold for the rest of the year. This situation renders the simple runoff estimation useless because more water flows per unit area from an unglacierized basin than a glacierized one. Several assumptions concerning meltwater from different parts of the basin were made to correct this imbalance, resulting in speculative answers. If the results are reasonable, then the highly variable spring runoff, which stabilizes in May as the glacial discharge increases, may be caused by the irregular nature of water storage in glaciers. Another factor influencing the runoff variation may be the year-to-year change in the start of the melt season. The minimum variation in late summer is to be expected, when runoff produced by icemelt compensates for lack of precipitation. The estimated $C$ values for this hypothetical glacier covered basin are, in general, more variable than for the other two less glacierized basins.

\section{SUMMARY}

Glacier modulation of runoff is manifested in the delay of runoff caused by its temporary storage of water as ice. The release of this stored water results in a volume contribution to mean runoff, particularly during drought years. If a glacier has a negative balance year of $1 \mathrm{~m}$ WEQ and a basin is $20 \%$ glacier covered, runoff can be $10 \%$ greater than would be expected from a nearby comparably sized unglacierized basin of similar precipitation characteristics. This assumes an unglacierized runoff value of $2 \mathrm{~m}$, which is typical for the North Cascades. Because the ice melts during the summer, this same balance value increases summer runoff by about $50 \%$ over an unglacierized basin, assuming $15 \%$ of the annual unglacierized runoff occurs during July and August.

The presence of glaciers in a basin also delays the time of maximum seasonal runoff. This delay is caused by temporary liquid storage of spring meltwater in the glacier, which is released later in the summer, and by the peak meltwater production occurring in midsummer. In May 1970, the storage of spring meltwater in South Cascade Glacier accounted for $54 \%$ of the total potential May runoff. The change in runoff delay is greater for differences in glacierization of basins with small glacier cover and smaller in basins with large cover. For example, the maximum runoff of a $7 \%$ glacierized basin occurs almost a month after that of a nonglacierized basin, whereas the maximum runoff from a $100 \%$ glacier-covered basin is only 2 weeks later than from a basin that is $50 \%$ glacierized.

The annual coefficient of variation changes with the fraction of glacierization. The existing data set was too sparse to permit direct analysis, so an algorithm, based on the statistics of annual runoff from two basins of different glacier cover, was used to estimate the coefficient of variation of runoff for a basin with any glacier cover. The results show that the coefficient of variation decreases rapidly with increasing glacierization at small glacier covers, reaching a minimum at $36 \%$ glacier cover. The variation then increases with increasing glacierization to $100 \%$ glacier cover, at which point the variation is almost equal to that of a nonglacierized basin.

The monthly runoff variations show a minimum in April through May for unglacierized basins, and a maximum in 
March and April for basins $100 \%$ glacierized. The minimum is caused by snowmelt compensating for rainfall variations in unglacierized basins, and the maximum, if not an artifact of the analysis, may be caused by irregular water storage in the glacier, resulting in a greater variation in runoff from highly glacierized basins. The minimum coefficient of variation occurs in July, August, and September, when the icemelt compensates for deviations in precipitation, and appears for basins with more than about $10 \%$ cover.

\section{SUGGESTIONS FOR FURTHER WORK}

One of the interesting implications of this study is the possibility of inferring the change in area of glaciers from the runoff records of a basin. The timing of the maximum summer flow and how it has changed over a number of decades might be used to infer changes in glacier cover if the area of the basin covered by glaciers is known at any one time. The recent glacial history may be inferred for those regions that lack good aerial photographic documentation.

Acknowledgments. We thank L. A. Rasmussen, U.S. Geological Survey, Project Office-Glaciology, for helping us to focus our study and for his detailed reviews from which much was learned. We also gratefully acknowledge the assistance of $D$. Lettenmaier of the University of Washington, Department of Civil Engineering whose perspicacious suggestions concerning the statistics of the linear combination of runoff from basins with different glacier cover greatly aided our presentation.

\section{REFERENCES}

Henshaw, F. F., Notes on variation of runoff on the Pacific Slope, Eos Trans. $A G U, 14,431-435,1933$.

Krimmel, R. M., and W. V. Tangborn, South Cascade Glacier: The moderating effect of glaciers on runoff, paper presented at Western Snow Conference, Anchorage, Alaska, April 1974
Larson, Graham J., Meltwater storage in a temperate glacier, Burroughs Glacier, Southeast Alaska, Rep. 66, Inst. of Pol. Stud., Ohio State Univ., Columbus, 1978.

Meier, M. F., Glaciers and water supply, J. Am. Water Works Res., $6 I(1), 8-12,1969$.

Meier, M. F., and W. V. Tangborn, Distinctive characteristics of glacier runoff, U.S. Geol. Surv. Prof. Pap., 424-B, 14-16, 1961.

Ostle, B., and R. W. Mensing, Statistics in Research (3rd ed.), pp. 40-41, Iowa State University Press, Ames, Iowa, 1975.

Paterson, W. S. B., The physics of glaciers (2nd ed.), p. 44, Pergamon, New York, 1981.

Post, A. P., D. Richardson, W. V. Tangborn, and F. L. Rosselot. Inventory of glaciers in the North Cascades, Washington, U.S. Geol. Surv. Prof. Pap., 705 A, 1971.

Rasmussen, L. A., and W. V. Tangborn, Hydrology of the North Cascades region, Washington, 1, Runoff, precipitation, and storage characteristics, Water Resour. Res., 12, 187-202, 1976.

Stenborg, Thorsten, Delay of runoff from a glacier basin, Geografiska Annaler, 52, Ser, A, 1-30, 1970.

Tangborn, W. V., R. M. Krimmel, and M. F. Meier, A comparison of glacier mass balance by glaciological, hydrological and mapping methods, South Cascade Glacier, Washington, IAHS-AISH Publ., $104,185-196,1975$

U.S. Geological Survey, WATSTORE user's guide, U.S. Geol. Surv. Open File Rep., 75-426, I, B1-B48, 1975.

Zuming, Lai, A study on the variation coeflicient of annual runoff of the rivers of Northwest China: Hydrological aspects of Alpine and high mountain areas, Exeter, July 1982, IAHS-AISH, Publ., I38, 285-294, 1982.

A. G. Fountain, Project Office-Glaciology, U.S. Geological Survey, 1201 Pacific Avenue, Suite 450, Tacoma, WA 98402.

W. V. Tangborn, Hymet Company, 2366 Eastlake Avenue East, Seattle, WA 98102 .

(Received July 9, 1984;

revised December 19, 1984 ;

accepted December 20, 1984.) 